The University of San Francisco

USF Scholarship: a digital repository @ Gleeson Library | Geschke Center

\title{
The Local and Global Politics of Contemporary Art
}

John Zarobell

University of San Francisco, jzarobell@usfca.edu

Follow this and additional works at: https://repository.usfca.edu/international_fac

Part of the International and Area Studies Commons

\section{Recommended Citation}

Zarobell, J. (2017). The Local and Global Politics of Contemporary Art. China Review International 24(4), 266-271. doi:10.1353/cri.2017.0065.

This Article is brought to you for free and open access by the International Studies at USF Scholarship: a digital repository @ Gleeson Library | Geschke Center. It has been accepted for inclusion in International Studies Faculty Publications by an authorized administrator of USF Scholarship: a digital repository @ Gleeson Library | Geschke Center. For more information, please contact repository@usfca.edu. 
carriages into the imperial palace. Gaozong likewise condemned these practices as improper. Liu et al., Jiu Tangshu, 45.1957.

23. Sanping Chen, Multicultural China in the Early Middle Ages (Philadelphia: University of Pennsylvania Press, 2012), pp. 157-182, esp. 173.

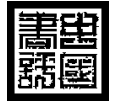

\section{The Local and Global Politics of Contemporary Art}

Frank Vigneron. Hong Kong Soft Power: Art Practices in the Special Administrative Region, 2005-2014. Hong Kong: Chinese University Press, 2018. xxi, 390 pp. Hardcover \$60.00, ISBN 978-962-996-804-5.

As I write this review, protesters have recently gathered in nearly unprecedented numbers in Hong Kong (over a million according to the organizers, in a march that extended more than a mile in length) to protest the "evil law" that aims to allow extradition requests to be honored in Hong Kong. For outsiders like myself, this seems like much ado about little since extradition treaties are normal among states. But for insiders, the implication is rather different and the law has caused an enormous political backlash. If it becomes possible for residents of the Special Administrative Region of Hong Kong to be legally extradited, that will open the floodgates for the Communist Party to call anyone they want to the People's Republic to face a judiciary that is not considered by these residents to be independent. While the protests do not seem to have impacted Hong Kong's current leader, Carrie Lam, images of the protest have been broadcast all around the world, including the cover of the New York Times and the vote on the law has been delayed as protests continue. This is soft power in action-even if the protesters cannot change the outcome of this legislative process, they are demonstrating that they do not support it and that it is being forced upon them so that everyone will know that the law is violating the will of the people.

In his expansive volume on recent art practices in Hong Kong, Frank Vigneron tries to zero in on this political dynamic in the art works made in the Special Administrative Region over a decade. Even in the face of shifting

(C) 2019 by University of Hawai $i$ Press power dynamics and market-driven economy that tends to marginalize artists, many contemporary artists of the city seek to promote social change through their work. This book provides a subtle and theoretically-rich analysis of a variety of contemporary art and artists, or "plasticians" as the author usually 
refers to them. Written by Frank Vigneron, Professor and Chair of the Fine Arts department at the Chinese University of Hong Kong, it presents the complexities of contemporary artistic production in Hong Kong, from traditional painting and ink art to relational aesthetics and, in the process, situates contemporary art in Hong Kong in relation to a variety of art world trends from mainland China to Europe and North America. Vigneron is a highly knowledgeable guide, having chronicled much of the development of contemporary art through his art criticism, his academic articles, and his previous book, I Like Hong Kong: Art and Deterritorialization (Columbia University Press, 2010). The main contribution of this new work is to shift from a primarily theoretical model to one that chronicles social and political developments and institutional structures that undergird the field of contemporary artistic production.

Vigneron was born in Hong Kong and is an artist himself (one of his three PhD's is in art production) but he is also something of a philosopher, who cites primarily Western theorists who have written on art and society, from Giles Deleuze and Félix Guattari to Slavoj Zizek and Nicholas Bourriaud. But his lodestar in this volume is Pierre Bourdieu and it is fair to say that this analysis sits somewhere between art history and sociology, which is provocative territory and well-suited for an analysis of culture in a city like Hong Kong, with its colonial past, capitalist ethos, and special political status. Vigneron is clearly responding to some of the most potent issues of the era, in which global contemporary art is getting made far beyond the domain of Europe and North America and local traditions can both contrast and harmonize with an emergent global culture. How is it possible to account for artistic developments in Hong Kong between 2005 and 2014 to readers, like myself, who have never visited the city and who may have seen the works of a few of its more notable artists but do not comprehend the context and significance for the production of these works?

This is a major undertaking and the reading is not light. The book is 376 pages, printed in double-column text, and the author employs a rich historical fabric of modern art history in China (the Lignan School, the May Fourth Movement) that are not well known outside of the field, as well as a very sophisticated theoretical apparatus. Within its own domains-modern Chinese art history, Asian contemporary artistic culture, studies of globalization-this work provides a significant contribution. The first chapter is a meticulous exploration of the development of artistic culture in Hong Kong during these years, the various cultural development schemes, the diverse and overlapping bureaucratic structures within the metropolitan government for supporting the arts, and the institutions: large, permanent, small, fugitive, and as yet unrealized. He addresses the political developments during this period, including the Umbrella Movement of 2014, as significant metrics of the city's 
relationship to the People's Republic and he investigates the role of artist in the market system that is anchored by one of the world's largest art fairs, Art Basel Hong Kong. In the process, he questions many fundamental assumptions among writers on contemporary art, investigating the complexities of concepts such as art criticism, the museum, and curating, among others. All of this is meant to demonstrate the complex "ecosystem" of Hong Kong visual arts and he is able to trace a variety of social and political commitments among the artists and practitioners he examines in these pages.

The second chapter is where he develops the theoretical grounding of the project, exploring Bourdieu's concept of habitus as a means of explaining the various approaches to art making that exist today and questioning the idea of any universal norms that could stand in a critique of art works in our current situation. He develops, following Rosalind Krauss c. 1970, a structuralist framework (a Piaget diagram) that seeks to sort the various overlapping and contingent dimensions of the "art world" in Hong Kong today. If all of this sounds a little old-fashioned by way of method, the author is completely up-todate in his understanding and analysis of globalization, network theory and the way artists in Hong Kong are devising new means to employ both traditional and novel material into politically engaged and socially conscious works of art. At times avuncular, and systematically didactic, the author's tone is nevertheless enlightening because he reads both art works and social developments in Hong Kong from both outside and inside. Vigneron is able to illuminate the necessary specifics of the historical situation through a lens of global social theory and art practices beyond the frame. By doing so, he makes an important contribution to the relationship of the local to the global in terms of artistic developments today. In this sense, it is an essential piece of the history of contemporary art in the twenty-first century.

Vigneron is at his best in the last chapter of the book, where he blends a highly sophisticated reading of recent social theory with the divergent art practices of contemporary artists in Hong Kong, referring to this under the broad theme of "relational aesthetics." While this term is one among many that attempts to fix the dialogic dynamic that many contemporary art practitioners aspire to in the twenty-first century, it allows him to draw from the deepest reserves of philosophical speculation on questions such as the role of the work of art in relation to society and the state, in this case applying such formulations to the particular problematic between a distant dominating People's Republic and the quasi-independent Special Administrative Region. Vigneron is quite engaging when he unpacks the relationship between image, language and practice, unlocking the complexity of contemporary Chinese art for a new audience that may lack the training and language skills to interpret it in its proper context. 
The question of deterritorialization from his last book comes back with a vengeance since both in the theoretical and practical domains Hong Kong artists are seeking to open up new territory in the name of freedom of thought and of action. While such a political process is clear enough to see in the consistent protests in Hong Kong that demonstrate the desire for autonomy among its residents, in the last two chapters he demonstrates how novel practices among contemporary artists make a particular contribution to the political and social dynamics in Hong Kong. One particularly rich example is the Wooferten Collective's series of exhibitions at the Shanghai Street art space, one of which was titled: Yau Ma Tei Self-Rescue Project and Demonstration Exhibition. In this project, a group of artists collected photographs and other memorabilia from the local neighborhood that was being demolished to make way for development. The artists used these elements in an effort to engage the local public politically. As the collective wrote in their statement:

We encourage the public not just to appreciate, cherish their community, but also through their action and participation to help preserve all of the precious things that constituted the lively district. Our everyday livelihood are [sic] in fact being subjected to more and more control, as urban renewal joined hands with developers, allowing giant entrepreneurs sprawling crawls [sic] affecting almost every aspects of our daily lives. We surely do not have any real "weapons" to fight against them, but why not do something and start our resist[ance] with our bare hands. (p. 329)

This novel strategy of curating personal objects from, in this case, Painter Fung's stall, to repurpose memories of a neighborhood towards political agitation among its residents suggests the tactics that artists have employed in order to respond to, if not transform, the political dynamics in their midst. By presenting projects such as these in his account of contemporary art in Hong Kong, Vigneron has properly chronicled the emergent techniques both in contemporary art and political practice among the denizens of the city.

Such an ambitious text however is liable to run up against some challenges. Vigneron is clearly more comfortable with discussions of (European) social theory and their implications in the art world than he is when he works to develop the meaning of soft power, which does not come up directly in the text. One wonders whether the title was chosen by the author or by another reader who perceived the usefulness of this term when it is applied to the practical tactics narrated by Vigneron. While the author seems endlessly fascinated with the complexities of terms like the self, social engagement, and the potential of education, he does not apply the same level of analysis to the concept of power and the distance between the exercise of power by an authoritarian state versus a subsidiary region or a museum director. If hard power is a question of arms and finance, soft power offers an alternative means of articulating how cultural products might have a political impact. This 
theory, an elaboration of the model originally developed by Joseph Nye, would ideally explain how a small region like Hong Kong might have an outsize influence in the global domain of the arts. Or it could explain how Hong Kong's complex cultural establishment might have an impact on the cultural policy, if not the political vision, of the People's Republic.

In fact, Vigneron does not arrive at either. Instead he explains the cultural developments-including art works, but also cultural products like exhibitions, journals and institutions-as expressing a kind of political or social development, one in which progress is no longer relevant and innovation seems obsolete. While I am inclined to agree with the author's view that, for example, ideas of traditional and contemporary art not usefully descriptive in charting the relationship between various modes of art production today, it is more challenging to perceive how a concept like "stimulus" or "emancipatory potential" is received by individuals, institutional structures, or the state. $\mathrm{He}$ makes the point that most of these artists and exhibitions are "preaching to the converted," and does investigate artists that have departed from the art realm entirely, like Chow Chun Fai who determined that in order to have an impact he needed to abandon the artistic path entirely and run for legislative office in 2012. But he also points out that no one expected him to win without addressing whether such a political act could be considered seriously as an art work, or a political project, and on what terms? If artists seek to influence the powerful, how is this possible given the trivialization of artistic projects that Vigneron himself analyzes in the media coverage of the arts?

Another problem is a certain blind spot in terms of the notion of the contemporary itself. The author develops a lot of theoretical strategies for circumnavigating this central problematic because the word is ance a description of the present and a means of signifying a historical development in the arts characterized by a particular attitude if not a style. Vigneron employs the term "plastician," an awkward if direct translation of a term common in French art history since the postmodern era that has no English equivalent. The author explains that he is carrying over this practice from his last book because terms like "contemporary art' is an expression only used for certain types of art like installation, performance, video art and a very narrow range of paintings" (p. xviii). I disagree with this definition of contemporary art because, after all, art fairs are full of paintings, sculptures, and photographs and I am sure that dealers, collectors, and artists agree that these are all contemporary art. But the bigger problem is really what contemporary means when it comes to the arts. Does this mean the artist is still breathing (contemporary=not dead) or does it signify a kind of avant-garde in which one finds a group of artists who is interested in transgressing existing boundaries in the art sphere (so a progressive notion of art history is implicit)? Neither of these is satisfactory and Vigneron tells us as much but the problem is: What is 
the alternative? Other authors (Terry Smith, for example) have explored this question explicitly. The complexity around our current obsession with the present moment, and with immediate gratification allowed through images (selfies), including regimes for determining value and meaning, would bring a lot more complexity to this art historical conundrum.

To be fair, that is not the primary preoccupation of this volume but it would help to unite the various elements of the book since the relationship between artists in Hong Kong who make ink paintings and those who stage performances or write on public walls (graffiti) are very difficult to situate without the co-dependency that the term contemporary involves. This codependency is, in a way, the best argument that readers should make their way through this impressive volume. Even if one has never been to Hong Kong, it is a location that matters because all of us live in the same moment and see ourselves reflected in distant capitals in myriad ways. We are all challenged by the dynamics of decentralized market economics and governments that seem entirely unresponsive to the needs of their people. The artists and collectives, the venues and organisms that Vigneron chronicles, are significant because even if we do not belong to their territory, we share this moment of history and we own both the pitfalls and the possibilities that the relationship of art, society and politics generates.

John Zarobell

John Zarobell is associate professor and Chair of International Studies at the University of San Francisco. He focuses on globalization, art, and urban development and his most recent book is Art and the Global Economy (University of California Press, 2017).

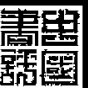

\section{The Monkey King, 4-EVER}

Hongmei Sun. Transforming Monkey: Adaptation and Representation of a Chinese Epic. Seattle: University of Washington Press, 2018. Hardcover \$95.00, ISBN 978-0-295-74318-9; Paperback \$30.00, ISBN 978-0-295-74139-6; E-book \$30.00, ISBN 978-0-295-74320-2.

This is a delightful work of literary history with the advantage of incorporating several media. The protagonist of the study, Sun Wukong-a.k.a. the Monkey 